International Journal of Advanced Academic Research (Social and Management Sciences) | ISSN: 2488-9849 Vol. 6, Issue 8 (August, 2020)|www.ijaar.org

\title{
BOARD ETHNIC DIVERSITY: DOES IT AFFECT CAPITAL STRUCTURE?
}

\author{
Maurice Adiga $\mathrm{ACA}^{1}$, Doka Lenge Shaki ${ }^{1}$, Victor Falack $\mathrm{FCA}^{1}$ \& Bassey, Emmanuel U. \\ ${ }^{1}$ Department of Accountancy, Taraba State University, Jalingo \\ ${ }^{2}$ School of Basic Studies, Taraba State University, Jalingo \\ Email: emmanueludebassey@gmail.com
}

\begin{abstract}
Objectives: The study examined the effect of board ethnic diversity on capital structure of listed agricultural companies in Nigeria. The study focused on the three major ethnic groups in Nigeria which included Igbo, Yoruba and Hausa-fulani.

Methodology: The expost facto research design was adopted and panel data used. The data was sourced from the published financial statements from NSE of the listed agricultural companies in Nigeria from 2015-2019. The data was subjected to diagnostic test for multicollinearity, normality and heteroscedasticity using VIF and Breach Godfrey test. OLS was used in testing the formulated hypotheses using SPSS 25.

Indicators: Ethnic diversity was measured as the ratio of Igbo, Yoruba and Hausa-fulani groups on the total board of directors while capital structure was measured as debt to equity.

Findings: The study holds that board ethnic diversity does not have a significant influence on the capital structure of firms.
\end{abstract}

Keywords: BOD, ethnicity, capital structure, equity, debt. 


\section{Introduction}

Demographic diversity at top management is a growing concern in the social, political and cultural perspective of corporate board members. Global concern has been drawn to corporate governance issues due to high profile corporate scandals experienced globally.

The Nigerian economy is a fast developing economy like other African economies, known for her multi-ethnic and multi lingual nature, the Nigerian business environment is not free from the criticisms of governance as it concerns fair ethnic representation in corporate organizations. The question is, does the representation of the majority ethnic groups (Igbo, Hausa-fulani, Yoruba) and others matter in enhancing fair value? Ethnic diversity to firm value has not been well addressed in the Nigerian context, this has given this study a unique standpoint.

In a business environment like Nigeria with diverse ethnic groups, the question of if ethnic composition in company's board of directors becomes inescapable. Business approach and perception to the ordinary Nigerian seem different between the major ethnic groups (Igbo, Yoruba and Hausa-fulani). The Igbos are viewed as very industrious and business oriented people with the business view of expanding and penetrating every possible business territory both home and abroad. With this perception, the option of loan as against equity is accredited to the Igbos as the option for expansion and the best capital composition decision. Whereas, the Yorubas and the Hausa-fulani are seen as more reserved though seeking expansion in business but not at the pace of the Igbos. This has informed the study to empirically examine the effect of ethnic differences in the capital composition of listed agricultural firms in Nigeria.

$\mathrm{H}_{\mathrm{o} 1}$ : Hausa-fulani ethnic group on BOD does not have any significant effect on capital structure.

$\mathrm{H}_{\mathrm{o} 2}$ : Yoruba ethnic group on BOD does not have any significant effect on capital structure.

$\mathrm{H}_{\mathrm{o} 3}$ : Igbo ethnic group on BOD does not have any significant effect on capital structure.

\section{Ethnic Diversity}

Board ethnic diversity is viewed as the level of ethnic diversity measured as a variation in the ethnic composition of the Board of Directors, whereas the ethnicity of the Board of Directors is determined by the largest proportion of directors that belong to a particular race. According to Zainal et al. (2013), ethnicity and firm performance has a positive and significant relationship in the Malaysian context. Some researchers have found that there is no relationship between ethnic diversity and firm financial performance in Malaysia (Monks, 2005). Hence, results are inconsistent regarding ethnic diversity. Hassan, Marimuth, Tariq and Aqeel (2017) researched effect of ethnic diversity in top management teams (TMTs). It was found that there is no effect on the firm performance if the company goes for the ethnic diversity.

Hambrick, Cho and Chen (1996) discussed advantages of having ethnic diversity in board. Ethnic diversity broadens knowledge, idea and experience through the range of information resources of different cultural background among the board members. An organization with high level of cultural heterogeneity in management is able to share ideas and reach ultimate 
decision based on the various thinking and thus, will improve management performance through a common consensus among the multiracial group of the boards. Thus, large ethnic diversity may improve firm performance by sharing and reaching ultimate decision (Shukeri, Shin \& Shaari, 2012).

Awaworyi and Valenzuela (2019) posit an unfavorable performance of firms with high levels of ethnic associations on the board. Hassan, Marimuthu and Johl (2015) Malaysian study showed that ethnic diversity is negatively associated with market value of firms.

An early study by Marimuthu (2009) showed ethnic diversity enhances firm financial performance in the Malaysian context. Cheong and Sinnakkannu (2014) study found a significant positive relationship between ethnic diversity and firm financial performance and that financial performance of companies differ between ethnicities.

\section{Capital Structure}

The pioneer of this debate and studies on capital structure theory is Modigiliani and Miller (1958). Capital structure decisions are among the most important and crucial decisions for any business because of their effect on the firm. The question of the appropriate capital mix for the decision of survival and growth is core to maintaining the going concern of the firm. Capital structure is one of the most important areas in financial decision. This is because of the relationship it has with other financial decisions variables. Capital structure is seen as the overall configuration of long term funds at the disposal of an enterprise for the pursuit of its objectives (Ekwueme \& Atu, 2018). A study by Ong and Teh (2011) opined that capital structure is a mixture of a company's debts (long-term and short-term), common equity and preferred equity. The theory of corporate debt capacity \& capital structure suggests that any given combination of debt instrument in equity capital employed by a business at any given point in time has significant implications for various managerial actions especially those concerning future solvency \& profitability (Osazie, 1985). Pandey (2010) defined capital structure as the various means of financing a firm, that is, the proportionate relationship between debt and equity. Pandey (2010) further stated that capital structure is a significant managerial decision because it influences the shareholder's return and risk as the market value of the share may be affected by the capital structure decisions.

If a company has higher debt rather than equity that the company doesn't make higher income because for the higher debt company need to pay higher interest which creates lower profit, on the contrary for the equity company, no need to pay interest but it provides dividend to the shareholder, if the company can make a good profit it can pay high dividend. So, a company needs to fix a balance between debt and equity (Weston and Brigham, 1979; Hossain, Khan \& Khalid, 2019).

\section{Social Impact Theory}

The social impact theory (Latane, 1981) explains that the amount of influences exercised in a group is anchored on strength (power or social status) of the group, immediacy (physical or psychological distance) of the group and the number of people in the group exerting the social influence (number of sources). This can depict that a set that have more members, a close proximity, high power should exert a considerable influence on decisions. 
Minority influence is said to occur when a minority subgroup attempts to change the majority (Rashotte, 2007). Researchers have often defined the process of social influence as the majority outmuscling the minority.

The major ethnic groups in Nigeria are the Igbo, Yoruba and the Hausa-fulani, in tackling capital structure optimization, the question is do the three major ethnic groups exercise influence on capital decisions on the board? Considering social impact assumptions, the three major ethnic groups are supposed to possess greater amount of influence in corporate boards due to their number and position as ethnic majority.

\section{Methodology}

The study classifies the ethnic groups in Nigeria into three (3) keeping in mind the above 250 ethnic groups in the country. All board members from the North Central, North East and North West are classified under Hausa-Fulani, all board members from South-south and South East are classified under Igbos while all board members from South West are classified as Yoruba. Foreign representation is held constant. The expost facto design was adopted and data was sourced from NSE published financial reports of the five (5) listed agricultural companies in Nigeria. The panel data covered the period of 5 years (2015-2019). The agricultural sector over the past one decade has received a considerable though not satisfactory economic focus in the mission for economic diversification in Nigeria with diverse expansion avenues created by both public (government) and private institutions.

The study was guided by a regression model:

$\mathrm{CS}=\alpha_{\mathrm{o}}+\alpha_{1}$ Eth + ę

The model is enlarged thus:

Dte $=\beta_{\mathrm{o}}+\beta_{1} \mathrm{Hf}+\beta_{2} \mathrm{Yrb}+\beta_{3} \mathrm{Ig}$

Where $\beta_{1}, \beta_{2}$ and $\beta_{3}$ represents $\alpha_{1}$

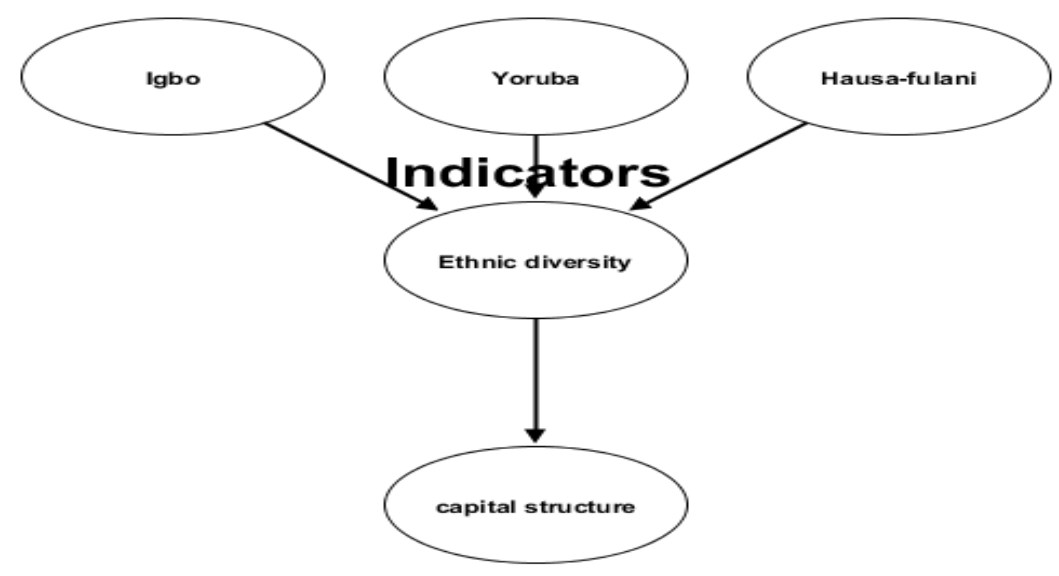

Figure 1: Conceptual model of influence of board ethnic diversity and capital structure Source: Authors Model (Adanco) 


\begin{tabular}{|l|l|l|}
\hline \hline Variable & Proxy & Measurement \\
\hline Capital structure & Debt to equity & Long-term debt/long-term debt + total equity \\
\hline Board Ethnicity & $\begin{array}{l}\text { Igbo (Ig) } \\
\text { Yoruba (Yrb) } \\
\text { Hausa-fulani (Hf) }\end{array}$ & $\begin{array}{l}\text { Ratio of Igbo to total directors } \\
\text { Ratio of Yoruba to total directors } \\
\text { Ratio of Hausa-fulani to total directors }\end{array}$ \\
& \\
\hline
\end{tabular}

\section{Data analysis}

The data was subjected to diagnostic test for multicollinearity, normality and heteroscedasticity using VIF and Breach Godfrey test. The standardized coefficient was explained for comparison purpose. Fixed and random effect was carried out, and the random effect was best considered.

Model Summary

\begin{tabular}{|l|l|l|l|l|}
\hline Model & $R$ & R Square & $\begin{array}{l}\text { Adjusted R } \\
\text { Square }\end{array}$ & $\begin{array}{l}\text { Std. Error of the } \\
\text { Estimate }\end{array}$ \\
\hline 1 & $.594^{\mathrm{a}}$ & .352 & .260 & .2730736 \\
\hline
\end{tabular}

a. Predictors: (Constant), Ig, Hf, Yrb

The adjusted $\mathrm{R}^{2}$ indicates that $26 \%$ of the dependent variable (capital structure) measured as debt to equity is explained by the predictive variables captured in the study. The variables not included in the model have $74 \%$ influence on the dependent variable.

ANOVA $^{a}$

\begin{tabular}{|ll|l|l|l|l|l|}
\hline \multicolumn{1}{|l|}{ Model } & Sum of Squares & Df & Mean Square & F & Sig. \\
\hline \multirow{4}{*}{1} & Regression & .852 & 3 & .284 & 3.810 & $.025^{\mathrm{b}}$ \\
& Residual & 1.566 & 21 & .075 & & \\
& Total & 2.418 & 24 & & & \\
\hline
\end{tabular}

a. Dependent Variable: Debt to equity

b. Predictors: (Constant), Ig, Hf, Yrb

The p-value (0.025) shows that the predictors jointly have a significant effect on capital structure of listed agricultural companies at $5 \%$ stochastic error term.

Coefficients $^{\mathrm{a}}$

\begin{tabular}{|c|c|c|c|c|c|c|c|c|}
\hline \multirow{2}{*}{\multicolumn{2}{|c|}{ Model }} & \multicolumn{2}{|c|}{$\begin{array}{l}\text { Unstandardized } \\
\text { Coefficients }\end{array}$} & \multirow{2}{*}{\begin{tabular}{|l|}
$\begin{array}{l}\text { Standardized } \\
\text { Coefficients }\end{array}$ \\
Beta
\end{tabular}} & \multirow[t]{2}{*}{$\mathrm{T}$} & \multirow[t]{2}{*}{ Sig. } & \multicolumn{2}{|c|}{ Collinearity Statistics } \\
\hline & & $B$ & Std. Error & & & & Tolerance & VIF \\
\hline \multirow{4}{*}{1} & (Constant) & .896 & .193 & & 4.641 & .000 & & \\
\hline & $\mathrm{Hf}$ & .217 & .479 & .094 & .452 & .656 & .718 & 1.392 \\
\hline & Yrb & -.373 & .248 & -.347 & -1.503 & .148 & .578 & 1.730 \\
\hline & Ig & -.798 & .238 & -.686 & -3.352 & .003 & .735 & 1.360 \\
\hline
\end{tabular}

a. Dependent Variable: debt to equity 
The standardized coefficients show the Beta value for comparative analysis of the individual predictors. The coefficient value for Hf .094 and a p-value .656 indicates a positive but insignificant effect of Hausa-fulani ethnic group on capital structure. This implies that a unit change in Hf ethnic director on BOD will shift capital composition decision by $9.4 \%$ though insignificant to the board final decision. Yoruba ethnic group coefficient value -.347 and pvalue 148 implies a negative and insignificant effect on capital structure. The Igbo ethnic group coefficient value shows -.686 with a p-value .003 indicating a negative but significant effect on capital structure.

\section{Study implication}

The study considered ethnic difference among the board of directors in the Nigerian context. Agricultural companies listed with Nigerian Stock Exchange were sampled. The findings of the study are relevant in the industry as it will aid policy formulation and implementation on corporate governance with regards to the demographic characteristics of board of directors. Corporate agencies like CBN, FIRS, SEC, NSE will find the study result important in decision making and strategic planning. The agricultural sector will appreciate the result of the study in appraising the how board ethnic diversity influences capital composition of firms.

\section{Conclusion}

Board ethnic diversity is a contemporary issue in corporate governance. The increased attention of stakeholders on the state of corporate entities has broadened the search light of practitioners and researchers. Ethnic differences of board of directors have an influence on the capital mix decision of corporate entities in Nigeria. The capital mix is not tied up to a particular ethnic group, the findings revealed that the presence of Igbo, Yoruba and Hausafulani on the BOD foster loans and equity as a mix of capital composition while the absence of any of the ethnic groups does not engineer significant changes in the capital structure of agricultural firms. The study holds that board ethnic diversity does not have a significant influence on the capital structure of firms.

\section{Recommendations}

The study recommends base on the findings that firms should not be ethnic bias in the composition of Board of Directors. An even representation of the ethnic group will create room for diverse ideas towards the achievement of firm's objectives. 


\section{References}

Cheong, C.W.H \&Sinnakkannu, J. (2014). Ethnic Diversity and Firm Financial Performance: Evidence from Malaysia. Journal of Asia-Pacific Business, 15, 73-100.

Ekwueme, C.M \&Atu, O.G. (2018). Capital Structure and Firms Financial Performance in Nigeria Quoted Insurance Companies. Account and Financial Management Journal, 3(5), 1530-1542

Hambrick, D.C., T.S. Cho and M.J. Chen, (1996). The influence of top management team heterogeneity on firms' competitive moves. Administrative Science Quarterly, 41(4), 659684.

Hassan, R., M. Marimuthu and S.K. Johl, (2015). Ethnic diversity on boards and market performance: An empirical investigation in Malaysia. Advanced Science Letters, 21(5), 1099-1103.

Hassan, Rohail; Marimuth, Maran; Tariq, Eraj; and Aqeel, Raja (2017). Ethnic and Gender Diversity in Top Level Management and Firm Performance: Shareholder's Perspectives.Journal of International Women's Studies, 18(4).

Latane, B. (1981). The psychology of social impact. American Psychologist, 36, 343-356.

Marimuthu, M. (2009). Ethnic and Gender Diversity in Board of Directors and Their Relevance to Financial Performance of Malaysian Companies. Journal of Sustainable Development, 2(3), 139-148.

Modigliani, F and Miller, M.H (1958). The cost of capital, corporate finance and theory of investment. America Economic Review, 48(2), 61 -97.

Monks, R.A.(2005). Corporate governance-USA-fall 2004 reform-the wrong way and the right way. Corporate Governance: An International Review, 13(2), 108-113.

Ong, T. S., \&Teh, B. H. (2011). Capital structure and corporate performance of Malaysian construction sector. International Journal of Humanities and Social Science, 1(2), 28-36.

Pandey, I.M (2010). Financial Management, Tenth Edition. New Delhi: Vikas Publishing Home PVT

Rashotte, L. (2007). Social influence. In G. Ritzer (Ed.), The Blackwell encyclopedia of sociology, Vol. IX (pp. 4426-4429). Malden, MA: Blackwell.

Shukeri, S.N., Shin, O.W \&Shaari, M.S. (2012). Does Board of Director's Characteristics Affect Firm Performance? Evidence from Malaysian Public Listed Companies. International Business Research, 5(9), 120-127

Zainal, D.,Zulkifli, N \&Saleh, Z.(2013). Corporate board diversity in Malaysia: A longitudinal analysis of gender and nationality diversity. International Journal of Academic Research in Accounting, Finance and Management Sciences, 3(1), 136-148. 